\title{
Asupan kafein dari kopi dan teh serta hubungannya dengan kepadatan tulang pada perempuan pascamenopause
}

\author{
Stella Verinda ${ }^{1}$, Elly Herwana ${ }^{2}$
}

\begin{abstract}
ABSTRAK
LATAR BELAKANG

Osteoporosis merupakan kondisi patologis tulang dengan karakteristik bone mineral density (BMD) yang rendah disertai perubahan mikroarsitektur jaringan tulang, sehingga meningkatkan risiko fraktur. Faktor risiko osteoporosis yaitu perempuan pascamenopause, genetik, indeks massa tubuh, aktivitas fisik, asupan gizi dan mineral, merokok, serta asupan alkohol, dan kafein. Penelitian ini bertujuan untuk menilai efek kafein dari kopi dan teh terhadap kepadatan tulang pada perempuan pascamenoapuse.
\end{abstract}

\section{METODE}

Penelitian ini merupakan penelitian analitik observasional dengan desain cross-sectional. Subjek penelitian adalah perempuan pascamenopause yang berusia $>40$ tahun berjumlah 92 orang. Asupan kafein dinilai dari total asupan yang berasal dari kopi dan teh dengan menggunakan kuesioner dan wawancara. Perhitungan asupan total kafein diperhitungkan dengan penyetaraan asupan kopi dan teh per minggu. Kepadatan tulang dinilai menggunakan alat calcaneal quantitative ultrasound untuk menetukan nilai-T sebagai parameter osteoporosis. Subjek dikelompokkan sebagai kepadatan tulang normal (nilai- $\mathrm{T} \geq-1$ ), osteopenia (nilai-T antara -1 sampai -2.5) dan osteoporosis (nilai-T<-2.5) Analisis statistik dilakukan untuk menilai hubungan kedua variabel dilakukan dengan uji Chi-square.

\section{HASIL}

Rerata (simpang baku) usia subjek adalah $57.84 \pm 7.57$. Sebanyak 26 (28.3\%) subjek dengan kategori osteoporosis, 50 (54.3\%) osteopenia, dan 16 (17.4\%) normal. Asupan kafein didapatkan 69 subjek (75\%) dengan kategori rendah dan $23(25 \%)$ tinggi. Hasil analisis didapatkan tidak terdapat hubungan yang bermakna antara asupan kafein dan kepadatan tulang $(\mathrm{p}=0.419 ; \mathrm{p}>0.05)$.

\section{KESIMPULAN}

Tidak terdapat hubungan antara asupan kafein dari kopi dan teh dengan kepadatan tulang pada perempuan pascamenopause.

Kata kunci: kopi, teh, kepadatan tulang, pascamenopause
${ }^{1}$ Program Studi Kedokteran, Fakultas Kedokteran Universitas Trisakti, Jakarta, Indonesia

${ }^{2}$ Departemen Farmakologi dan Farmasi Kedokteran, Fakultas Kedokteran Universitas Trisakti, Jakarta, Indonesia

\section{Korespondensi:}

Elly Herwana

Departemen Farmakologi dan Farmasi Kedokteran, Fakultas Kedokteran Universitas Trisakti, Jakarta, Indonesia Jalan Kyai Tapa Kampus B Grogol, 11440

Email: elly.herwana@trisakti.ac.id

J Biomedika Kesehat 2020;3(2):70-76 DOI: $10.18051 / \mathrm{JBiomedKes.2020.}$ v3.70-76

pISSN: 2621-539X / eISSN: 2621-5470

Artikel akses terbuka (open access) ini didistribusikan di bawah lisensi Creative Commons Attribution 4.0 International (CC-BY 4.0) 


\section{ABSTRACT}

\section{Caffeine intake from coffee and tea and its relationship to bone density in postmenopausal women}

\section{BACKGROUND}

Osteoporosis is a pathological condition of bone with a characteristic low bone mineral density (BMD) accompanied by changes in bone tissue microarchitecture thus increasing the risk of fracture. Osteoporosis risk factors are postmenopausal women, genetics, body mass index, physical activity, nutritional and mineral intake, smoking, alcohol and caffeine intake. This study aims to assess the effects of caffeine from coffee and tea on bone density in postmenopausal women.

\section{METHODS}

This study was an observational analytic study with a cross-sectional design. Subjects were 92 postmenopausal women $>40$ years old. Caffeine intake was assessed from the total intake from coffee and tea using questionnaires and interviews. Calculation of total caffeine intake is calculated by equalizing coffee and tea intake per week. Bone density was assessed using a calcaneal quantitative ultrasound to determine the T-Score as an osteoporosis parameter. Subjects were classified as normal bone density (T-value-1), osteopenia (T-value between -1 to -2.5 ) and osteoporosis (T-value <-2.5). Statistical analysis was performed to assess the relationship between the two variables with Chi-square test.

\section{RESULTS}

The mean (standard deviation) age of subjects was $57.84 \pm 7.57$. A total of $26(28.3 \%)$ subjects were categorized as osteoporosis, $50(54.3 \%)$ osteopenia and $16(17.4 \%)$ were normal. Caffeine intake was found in 69 subjects $(75 \%)$ with low categories and $23(25 \%)$ high. The analysis found that there was no significant relationship between caffeine intake and bone density $(\mathrm{p}=0.419 ; \mathrm{p}>0.05)$.

\section{CONCLUSION}

There was no significant relationship between caffeine intake from coffee and tea and bone density in postmenopausal women.

Keywords: coffee, tea, bone density, postmenopausal women

\section{PENDAHULUAN}

Osteoporosis adalah kondisi patologis pada tulang yang ditandai dengan penurunan kekuatan tulang akibat berkurangnya kepadatan tulang dan berdampak pada peningkatan risiko fraktur. Osteoporosis memiliki karakteristik bone mineral density (BMD) yang rendah dan perubahan mikroarsitektur jaringan tulang, sehingga tulang menjadi rapuh dan mudah patah. ${ }^{(1)}$ Proporsi penderita osteoporosis pada penduduk yang berusia lebih dari 50 tahun di Indonesia adalah $32.3 \%$ pada perempuan dan $28.85 \%$ pada laki-laki. ${ }^{(2)}$

Menopause merupakan fenomena alam yang terjadi akibat penurunan fungsi ovarium disertai berkurangnya produksi hormon estrogen. Menopause ditandai dengan berhentinya siklus haid secara permanen. Gejala premenopausal mendahului menopause. Fase setelah menopause disebut pascamenopause. Pada saat premenopause maupun pascamenopause terjadi peningkatan risiko osteoporosis. Pada umumnya, fase pascamenopause lebih panjang dibanding premenopause. Prevalensi osteoporosis pascamenopause meningkat sejalan dengan pertambahan usia, proporsi osteoporosis adalah satu diantara tiga perempuan pascamenopause dan meningkat hingga $50 \%$ pada usia $75-80$ tahun. ${ }^{(2,3)}$

Etiologi dari osteoporosis bersifat multifaktorial, banyak faktor turut berperan dalam patogenesis osteoporosis. Studi sebelumnya melaporkan mengenai faktor risiko yang dapat menurunkan kepadatan tulang, yaitu perempuan pascamenopause, genetik, indeks massa tubuh, aktivitas fisik, asupan gizi dan mineral, merokok, serta asupan alkohol dan kafein. ${ }^{(4-6)}$

Kepadatan tulang yang dinilai melalui pengukuran BMD merupakan karekeristik dari osteoporosis. Penilaian utuk kepadatan tulang yang dilakukan dengan menggunakan Calcaneal Quantitative Ultrasound Densitometry(QUS) akan menghasilkan nilai-T (T-score) sebagai parameter ukur untuk kepadatan tulang. Berdasarkan nilai-T, kepadatan tulang dikelompokkan sebagai normal, osteopenia, dan osteoporosis.

Kafein adalah alkaloid alam yang terdapat dalam kopi, teh, soda, dan coklat. Kafein (1,3,7-trimetilxantin) termasuk analepik yang banyak dikonsumsi sebagai minuman stimulan susunan saraf pusat. Minuman mengandung kafein terbanyak dikonsumsi, yaitu kopi dan teh. Konsumsi minuman dan makanan yang 
mengandung kafein di Amerika Serikat mencapai $85 \%$ dari kopi dengan total konsumsi sebanyak $89 \%$. Banyak studi yang telah dilakukan masih menunjukkan kontroversi mengenai efek kafein pada kesehatan. ${ }^{(7-8)}$ Asupan kafein yang berlebih dikaitkan dengan efek sampingnya terhadap jantung, risiko fraktur tulang, serta perubahan prilaku pada orang dewasa sehat, perempuan hamil, dan anak. ${ }^{(8)}$ Peningkatan prevalensi fraktur dan hubungannya dengan asupan kafein dikaitkan dengan efek kafein pada homeostasis kalsium yang merupakan mineral utama pada tulang. Asupan kafein yang tinggi ( $>560 \mathrm{mg}$ ) setara dengan 8 cangkir kopi meningkatkan risiko fraktur pada perempuan. ${ }^{(8)}$

Kafein meningkatkan ekskresi kalsium, sehingga potensial menginduksi terjadinya osteoporosis. ${ }^{(9)} \quad$ Peningkatan ekskresi kalsium melalui ginjal akan menstimuli aktivitas alkali fosfatase osteoblas ${ }^{(10)}$ dan menurunkan fungsi vitamin D. ${ }^{(10,11)}$ Hasil studi sebelumnya mendapatkan bahwa asupan kafein meningkatkan risiko osteoporosis pada perempuan pascamenopause usia 50-65 tahun dan efeknya dipengaruhi dosis. ${ }^{(12)}$ Sementara hasil studi lainnya menunjukkan hasil yang berbeda, asupan kafein tidak berhubungan dengan BMD pada laki-laki dan perempuan yang berusia $>50$ tahun. (13) Hasil studi lain mendapatkan bahwa asupan kafein bersifat protektif terhadap tulang dan berhubungan dengan nilai-T yang lebih tinggi pada laki-laki dan perempuan pramenopause. ${ }^{(14)}$ Berdasarkan berbagai hasil penelitian tersebut, penelitian ini bertujuan untuk menilai hubungan antara asupan kopi dan teh terhadap kepadatan tulang pada perempuan pascamenopause.

\section{METODE}

Penelitian ini merupakan studi analitik observasional dengan menggunakan desain crosssectional study (studi potong lintang). Penelitian ini dilaksanakan di Kelurahan Sudimara Barat, Tangerang, Banten. Subjek penelitian ini adalah perempuan pascamenopause alamiah yang tinggal di Kelurahan Sudimara Barat, Tangerang, Banten. Perempuan berusia $>40$ tahun yang telah mengalami menopause alamiah selama $\geq 1$ tahun, masih mampu berjalan sendiri dan berkomunikasi, serta bersedia untuk menandatangani informed concent menjadi kriteria inklusi pada penelitian ini. Perempuan yang mengalami menopause akibat pengangkatan rahim/ovarium, dalam terapi sulih hormon (TSH), menggunakan obat golongan kortikosteroid jangka panjang, atau suplemen yang mempengaruhi metabolisme tulang seperti kalsium, vitamin D, dan isoflavon, termasuk dalam kriteria eksklusi dan tidak diikutsertakan dalam penelitian ini. Perhitungan jumlah sampel dilakukan dengan menggunakan rumus finit-infinit sebagai berikut:

$$
\mathrm{N}=\mathrm{Z} \alpha^{2}(\mathrm{p} \times \mathrm{x}) / \mathrm{d}^{2}
$$

Berdasarkan prevalensi osteoporosis pada perempuan pascamenopause adalah $32.2 \%^{2}$ dengan tingkat kemaknaan sebesar $95 \%$ dan keakuratan adalah 0.05 , maka diperoleh perhitungan jumlah sampel yang diperlukan sebanyak 336 subjek penelitian. Pencatatan data untuk jumlah perempuan pascamenopause di kelurahan Sudimara Barat, Tangerang adalah 100 orang dengan menambahkan perhitungan dropout sebesar $15 \%$, maka jumlah sampel minimal yang dibutuhkan adalah 92 subjek.

Pemilihan subjek dilakukan secara consecutive sampling. Data sosiodemografi meliputi usia, lama menopause, dan asupan kafein dinilai melalui pengisian kuesioner dan wawancara. Asupan kafein diperhitungkan terhadap kuantitas asupan kopi dan teh yang diperhitungkan dan disetarakan dengan jumlah kafein dalam gram/ hari. Subjek diminta untuk mencatat frekuensi dan banyaknya (cangkir/gelas) minum kopi dan teh per hari untuk jangka waktu 1 minggu (7 hari). Asupan kafein diperhitungkan sebagai asupan kafein total/minggu ( $\mathrm{g} /$ minggu). Kandungan kafein dalam satu cangkir kopi (240 ml) sangat bervariasi, mengandung kafein antara 93-133 $\mathrm{mg} /$ cangkir, tergantung dari jenis dan banyaknya kopi yang digunakan. Penilaian kadar kafein per cangkir kopi diperhitungkan dengan nilai median yaitu $113 \mathrm{mg} /$ cangkir. Sementara satu cangkir teh mengandung kafein antara 47-78 mg/cangkir dan dipengaruhi jumlah dan jenis teh yang digunakan. Penilaian kadar kafein dalam teh diperhitungkan nilai median yaitu $62.5 \mathrm{mg} /$ cangkir. Rerata asupan kafein pada orang dewasa sehat ada di antara 300-400 mg/hari. ${ }^{(15)}$ Kriteria penggolongan asupan kafein rendah dan tinggi diperhitungkan atas perhitungan asupan kafein total selama satu minggu (7 hari) dengan titik potong asupan total 
kafein pada $2 \mathrm{~g} /$ minggu. Perhitungan asupan kafein dinilai untuk satu minggu atas pertimbangan adanya subjek yang tidak minum kopi atau teh setiap hari. Penggolongan hasil perhitungan asupan kafein dikelompokkan sebagai asupan kafein total rendah bilamana asupan kafein $<2$ g/ minggu dan asupan tinggi bilamana asupan total kafein adalah $\geq 2 \mathrm{~g} /$ minggu $^{(15)}$

Penilaian untuk kepadatan tulang dilakukan dengan menggunakan Calcaneal Quantitative Ultrasound Densitometry (QUS). Alat Calcaneal QUS mendeteksi gelombang suara untuk untuk mengukur densitas mineral tulang (BMD) yang dilakukan pada tulang tumit (os calcaneus) dan jari kaki. Hasil pengukuran menggunakan QUS menghasilkan nilai-T(T-score) sebagai parameter ukur untuk kepadatan tulang. Berdasarkan hasil nilai-T, subjek dikelompokkan sebagai kepadatan tulang normal (nilai-T $\geq-1$ ), osteopenia (nilai-T antara -1 sampai -2.5 ) dan osteoporosis (nilai-T $<-2.5$ ). ${ }^{(1)}$

Analisis univariat dilakukan untuk penilaian deskriptif analitik sebagai frekuensi dan persentase terhadap karakteristik dan sosiodemografik subjek. Analisis bivariat penelitian ini menggunakan uji Chi-square untuk menilai hubungan antara variabel bebas dan tergantung dengan tingkat kemaknaan 0.05.

Penelitian ini dilaksanakan setelah memperoleh ethical clearance dari Komisi Etik Penelitian Fakultas Kedokteran Universitas Trisakti dengan Nomor 149/KER-FK/VII/2017.

\section{HASIL}

Perempuan pascamenopause yang memenuhi kriteria inklusi dan ekslusi serta bersedia menandatangani informed concent dimasukkan sebagai subjek penelitian. Sebanyak 92 subjek penelitian yang berpartisipasi pada penelitian ini adalah mereka yang telah melengkapi pengisian kuesioner. Usia subjek penelitian menunjukkan nilai rerata (simpang baku) yaitu $57.84 \pm 7.57$. Usia subjek penelitian dikelompokkan sebagai usia $<48$ tahun dan $\geq 48$ tahun atas pertimbangan bahwa rerata usia menopause pada perempuan di Indonesia adalah 48 tahun. ${ }^{(2)}$ Perempuan yang mengalami menopause lebih awal akan lebih cepat mengalami osteoporosis. Hasil analisis didapatkan sebanyak $9(9.7 \%)$ berusia $<48$ tahun dan $83(90.2 \%)$ berusia $\geq 48$ tahun (Tabel 1).
Hasil penelitian ini juga menunjukkan bahwa sebanyak 41 (44.6\%) subjek mengalami menopause selama 1-5 tahun dan 51 (55.4\%) subjek mengalami menopause selama $>5$ tahun. Hasil penilaian terhadap asupan kafein total per minggu didapatkan sebanyak 69 (75\%) subjek mengonsumsi kafein dengan kategori rendah $(<2$ g/minggu) dan 23 (25\%) subjek mengonsumsi kafein dengan kategori tinggi $(\geq 2$ $\mathrm{g} /$ minggu). Hasil pengukuran kepadatan tulang yang dilakukan dengan calcaneal quantitative ultrasound, berdasarkan perhitungan nilai-T (T-score) didapatkan sebanyak 16 (17.4\%) subjek termasuk pada kategori kepadatan tulang normal (nilai-T $\geq-1)$, 50 (54.3\%) subjek dengan kategori kepadatan tulang rendah/osteopenia $(>-1$ nilai-T<-2.5), dan 26 (28.3\%) subjek penelitian dengan kategori kepadatan tulang sangat rendah/ osteoporosis (nilai $\mathrm{T} \leq 2.5$ ) (Tabel 1).

Tabel 1. Distribusi karakteristik subjek penelitian

\begin{tabular}{lcc}
\hline $\begin{array}{l}\text { Karakteristik } \\
\text { Responden }\end{array}$ & n & \% \\
\hline Usia & 9 & 9.7 \\
$<48$ tahun & 83 & 90.2 \\
$>48$ tahun & & \\
Lama menopause & 41 & 44.6 \\
$1-5$ tahun & 51 & 55.4 \\
$>5$ tahun & & \\
Asupan kafein total & 69 & 75.0 \\
Rendah & 23 & 25.0 \\
Tinggi & & \\
Kepadatan tulang & 16 & 17.4 \\
Normal & 50 & 54.3 \\
Osteopenia & 26 & 28.3 \\
Osteoporosis & & \\
\hline
\end{tabular}

Ket: $n=$ jumlah responde $(92) ; \%=$ persentase

Hubungan antara asupan kafein dan kepadatan tulang dianalisis dengan uji Fisher dan kepadatan tulang dikategorikan dalam 2 kelompok, yaitu osteoporosis dan tidak osteoporosis dengan titik potong nilai- $\mathrm{T} \leq 2.5$ untuk osteoporosis. Hasil penelitian menunjukkan bahwa subjek penelitian yang mengonsumsi kopi dan teh selama seminggu dengan kategori kafein total rendah $(<2 \mathrm{~g} /$ minggu) memiliki kepadatan tulang dengan kategori tidak osteoporosis (T-score >-2.5SD) sebanyak 52 (75.4\%) dan osteoporosis ( $T$-score $\leq-2.5$ ) sebanyak 17 (24.6\%). Hasil analisis penelitian menunjukkan bahwa subjek penelitian yang mengonsumsi kopi dan teh selama seminggu dengan kategori kafein total tinggi ( $\geq 2 \mathrm{~g} /$ minggu) memiliki kepadatan 
Tabel 2. Hubungan asupan kafein dan kepadatan tulang

\begin{tabular}{lcccc}
\hline \multirow{2}{*}{ Variabel $^{n}$} & \multicolumn{3}{c}{ Kepadatan tulang $(\mathbf{n = 9 2})$} & \multirow{2}{*}{ p $^{\text {b) }}$} \\
\cline { 2 - 4 } & Normal & Osteopenia & Osteoporosis & \\
\hline Asupan kafein $^{\text {a) }}$ & & & & \\
Rendah & $15(21.7)$ & $37(53.6)$ & $17(24.6)$ & 0.116 \\
Tinggi & $1(4.3)$ & $13(56.5)$ & $9(39.1)$ & \\
\hline
\end{tabular}

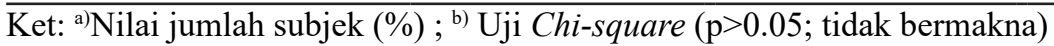

tulang dengan kategori normal sebanyak 15 $(65.2 \%)$ subjek penelitian, kategori osteoporosis sebanyak 8 (34.4\%) subjek penelitian. Hasil uji Fisher didapatkan nilai $\mathrm{p}=0.419$ yang diartikan bahwa tidak terdapat hubungan yang bermakna antara asupan kafein total dengan kepadatan tulang (Tabel 2).

Hasil penelitian juga menunjukkan bahwa subjek penelitian yang telah mengalami menopause selama 1-5 tahun memiliki kepadatan tulang dengan kategori normal sebanyak 7 (17.1\%) subjek, osteopenia 24 (58.5\%) subjek, dan osteoporosis $10(24.4 \%)$ subjek. Sementara subjek yang mengalami menopause selama $>5$ tahun menunjukkan kepadatan tulang dengan distribusi kategori normal 9 (17.6\%), osteopenia $26(51.0 \%)$, dan osteoporosis $16(31.4 \%)$.

Hasil evaluasi subjek dengan lama menopause, jumlah subjek dengan lama menopause $<5$ tahun dan lama menopause $\geq 5$ tahun menunjukkan distribusi jumlah yang tidak jauh berbeda. Pada kedua kelompok menunjukkan distribusi kepadatan tulang yang serupa, yaitu kelompok osteopenia merupakan proporsi tertinggi, diikuti kelompok osteoporosis, dan yang terendah adalah kepadatan tulang yang normal. Proporsi osteoporosis didapatkan lebih tinggi pada kelompok lama menopause $\geq 5$ tahun dibandingkan kelompok lama menopause $<5$ tahun, yaitu $31.4 \%$ dan 24.4\%. Hasil analisis statistik dengan uji Chisquare tidak didapatkan hubungan yang bermakna $(p=0.728 ; p>0.05)($ Tabel 3$)$.

\section{PEMBAHASAN}

Kopi dan teh merupakan minuman yang paling banyak dikonsumsi di seluruh dunia, sementara hasil studi terhadap efek kafein terhadap kesehatan masih kontroversial, demikian juga efeknya terhadap tulang. ${ }^{(8,9,16)}$ Hasil penelitian ini didapatkan bahwa tidak terdapat hubungan antara asupan kafein yang dinilai dari asupan kopi dan teh terhadap kepadatan tulang pada perempuan pascamenopause $(\mathrm{p}=0.419 ; \mathrm{p}>0.05)$. Namun hasil penelitian ini menunjukkan proporsi osteoporosis yang lebih tinggi pada kelompok dengan asupan kafein yang tinggi (34.8\%) dibandingkan dengan kelompok asupan kafein rendah (24.6\%). Banyak penelitian yang telah dilakukan terhadap efek kafein terhadap kesehatan tulang pada perempuan pascamenopause yang dilakukan dengan berbagai parameter penilaian yang berbeda. Penelitian sebelumnya dengan desain potong lintang memberikan hasil yang serupa dengan penelitian ini, asupan kafein tidak menunjukkan penurunan BMD yang bermakna. ${ }^{(13)}$

Studi kohort yang dilakukan pada 6034 perempuan di Swedia selama lebih dari 20 tahun menunjukkan bahwa asupan kafein yang lebih tinggi menunjukkan penurunan BMD dan sangat dipengaruhi dosis penggunaan kafein, tetapi tidak menunjukkan peningkatan kejadian fraktur. ${ }^{(16)}$ Sebaliknya hasil studi yang dilakukan di Taiwan, didapatkan bahwa asupan kopi yang lebih tinggi menunjukkan peningkatan nilai-T pada perempuan premenopause dan laki-laki. ${ }^{(14)}$ Peningkatan asupan kopi pada perempuan premenopause di Korea, tidak menunjukkan penurunan BMD yang bermakna pada pada collum femoris maupn lumbar spine. ${ }^{(17)}$ Hasil studi lainnya di Swedia didapatkan asupan kopi, teh, dan kafein yang tinggi berhubungan dengan peningkatan risiko osteoporosis, terutama bilamana disertai asupan kalsium yang rendah. ${ }^{(18)}$

Banyak penelitian dilakukan untuk menjelaskan patofisiologi pengaruh kafein terhadap tulang. ${ }^{(19-23)}$ Hasil penelitian yang menggunakan tikus sebagai hewan coba, asupan kafein selama 42 hari menunjukkan peningkatan kadar kalsium dalam plasma dan urin, penurunan kandungan kalsium pada tulang maksila dan penurunan kepadatan tulang yang bermakna dibandingkan kelompok kontrol. ${ }^{(19)}$ Efek kafein pada tulang banyak yang dikaitkan dengan homeostasis kalsium yang merupakan mineral utama tulang. Kafein meningkatkan ekskresi 
Tabel 3. Hubungan lama menopause dan kepadatan tulang

\begin{tabular}{|c|c|c|c|c|}
\hline \multirow{2}{*}{ Variabel } & \multicolumn{3}{|c|}{ Kepadatan tulang $(\mathrm{n}=92)$} & \multirow{2}{*}{$\mathbf{p}^{\text {b) }}$} \\
\hline & Normal & Osteopenia & Osteoporosis & \\
\hline \multicolumn{5}{|c|}{ Lama menopause ${ }^{a}$} \\
\hline$<5$ tahun & $7(17.1)$ & $24(58.5)$ & $10(24.4)$ & 0.728 \\
\hline$\geq 5$ tahun & $9(17.6)$ & $26(51.0)$ & $16(31.4)$ & \\
\hline
\end{tabular}

kalsium melalui ginjal. Penurunan kadar kalsium dalam darah akan menginduksi sekresi hormon tiroid dan meningkatkan resorpsi tulang serta menurunkan BMD. Asupan kalsium berhubungan dengan kepadatan tulang pada perempuan pascamenopause. ${ }^{(20-23)}$

Penelitian lain juga menghubungkan efek kafein terhadap vitamin D yang juga berhubungan dengan homeostasis kalsium. Kadar vitamin D didapatkan lebih rendah pada asupan kopi yang lebih tinggi pada kelompok usia dewasa muda di Korea. ${ }^{(11)}$ Kadar vitamin D yang lebih rendah berkaitan dengan penurunan fungsinya pada absorbsi kalsium di usus dan peningkatan reabsorbsi kalsium di ginjal disertai peningkatan kadar kadar kalsium urine. Efek kafein terhadap BMD juga dipengaruhi oleh asupan kalsium dan vitamin D. ${ }^{(10,11,24)}$

Sekalipun banyak penelitian telah dilakukan terhadap efek kafein pada tulang, namun mekanisme seluler yang sesungguhnya terjadi masih belum terbukti sepenuhnya. Studi in-vitro yang dilakukan pada jaringan tulang, didapatkan bahwa kafein mempengaruhi ekspresi protein dari reseptor vitamin D yang tergantung pada dosis pemberian. Pemberian kafein yang tinggi juga didapatkan penurunan kadar alkali fosfatase yang merupakan penanda diferensiasi sel osteoblas. ${ }^{(10)}$

Rerata usia menopause pada perempuan di Indonesia adalah pada usia 48 tahun. ${ }^{(2)}$ Hasil evaluasi penelitian ini terhadap hubungan antara lama menopause dengan kepadatan tulang menunjukkan kecenderungan kepadatan tulang yang lebih rendah dan persentase osteoporosis yang lebih tinggi pada kelompok perempuan dengan lama menopause $\geq 5$ tahun (31.4\%) dibandingkan dengan kelompok lama menopause $<5$ tahun (324.4\%). Usia merupakan faktor risiko yang berpengaruh pada osteoporosis pascamenopause. (25) Studi lain mendapatkan bahwa osteoporosis bukan merupakan penyakit yang disebabkan oleh penuaan, melainkan penyakit yang meningkat kejadiaannya bersamaan dengan penuaan. ${ }^{(26)}$
Penelitian ini memiliki beberapa keterbatasan, desain penelitian, desain cross sectional tidak dapat memberikan gambaran hubungan sebab akibat yang cukup kuat. Penilaian asupan kafein yang disetarakan dengan asupan kopi dan teh, banyak dipengaruhi variasi jenis kopi dan teh dengan kandungan kafein yang juga dapat berbeda. Faktor perancu yang dapat mempengaruhi kepadatan tulang seperti aktivitas fisik dan nutrisi tidak turut diperhitungkan dalam penelitian ini.

\section{KESIMPULAN}

Asupan kopi dan teh yang lebih tinggi tidak berhubungan dengan kepadatan tulang. Perlu dilakukan penelitian lebih lanjut dengan menggunakan rancangan penelitian seperti kohort dan memperhitungkan kandungan kafein dalam kopi dan the melalui analisis kimiawi.

\section{UCAPAN TERIMA KASIH}

Ucapan terima kasih terutama kepada perempuan pascamenopause yang telah bersedia berpartisipasi sebagai subjek penelitian ini dan kepada kepala Puskesmas Cileduk, Tangerang bersama jajarannya, serta semua pihak yang telah membantu hingga penelitian ini dapat terselesaikan.

\section{KONFLIK KEPENTINGAN}

Semua peneliti tidak memiliki konflik kepentingan terhadap hasil penelitian ini.

\section{KONTRIBUSI KEPENGARANGAN}

Stella Verinda dan Elly Herwana berkontribusi dalam penulisan naskah, pengumpulan dan analisis data. Elly Herwana berkontribusi dalam perbaikan penulisan naskah. Semua penulis telah membaca dan memberikan persetujuannya. 


\section{REFERENSI}

1. Ji MX, Yu Q. Primary osteoporosis in postmenopausal women. J Chron Dis Trans Med. 2015;1(1):9-13. doi: 10.1016/j.cdtm.2015.02.006

2. Pusat Data dan Informasi Kementrian Kesehatan RI. Data dan kondisi osteoporosis di Indonesia [Internet]. Jakarta: Pusat Data dan Informasi Kementrian Kesehatan RI; 2015. Available from: https://www.kemkes.go.id/ resources/download/pusdatin/infodatin/infodatinosteoporosis.pdf

3. Wright NC, Looker AC, Saag KG, et al. The Recent Prevalence of Osteoporosis and Low Bone Mass in the United States Based on Bone Mineral Density at the Femoral Neck or Lumbar Spine. J Bone Miner Res. 2014;29:2520-6. doi:10.1002/ jbmr.2269

4. Schürer C, Wallaschofsky $H$, Nauck $M$, et al. Fracture risk and risk factors for osteoporosis. Dtsch Arztebl Int. 2015;112: 365-7. doi: 10.3238/ arztebl.2015.0365

5. Tella SH, Gallagher JC. Prevention and treatment of postmenopausal osteoporosis. J Steroid Biochem Mol Biol. 2014;142: 155-170. doi:10.1016/j. jsbmb.2013.09.008

6. Pinherio MM, Reis Neto ET, Machado FS, et al. Risk factors for osteoporotic fractures and low bone density in pre and postmenopausal women. Rev Saúde Pública. 2010;44(3):479-485. doi: $10.1590 / \mathrm{s} 0034-89102010000300011$

7. Cornelis MC. The impact of caffeine and coffee on human health. Nutrients. 2019;11(2):416-9. doi:10.3390/nu11020416

8. Wikoff D, Welsh BT, Henderson R, et al. Systematic review of potential adverse effects of coffee consumption in healthy adults, pregnant women, adolescense, and children. Food Chem Toxicol. 2017 Nov;109(Pt1):585-648. doi: 10.1016/j.fct.2017.04.002

9. Kim SY. Coffee consumption and risk of osteoporosis. Korean J Fam Med. 2014; 35(1):1. doi: $10.4082 / \mathrm{kjfm} .2014 .35 .1 .1$

10. Al-Othman A, Al-Musharaf S, Al-Daghri NM, et al. Tea and coffee consumption in relation to vitamin $\mathrm{D}$ and calcium levels in Saudi adolescents. Nutr J. 2012;11:56. doi: 10.1186/1475-2891-11-56

11. Lim HS, Lee HH, Byun DW, et al. Serum vitamin D level related to coffee consumption in Korean young adults using the 5th Korea national health and nutrition examination survey. J Bone Metab. 2017;24(4):229-233. doi.org/10.11005/ jbm.2017.24.4.229

12. Kapetanović A, Avdic D. Influence of coffee consumption on bone mineral density in postmenopausal women with estrogen deficiency in menstrual history. J H Sci 2014;4(2):105-9. doi: 10.17532/jhsci.2014.194

13. Alshanbari MF, Alsofyani EM, Almalki DM, et al. Caffein effect on bone mineral density: A crosssectional study. JCDR 2018:12:OC14-17. doi: 10.7860/JCDR/2018/31216.11174

14. Chang HC, Hsieh CF, Lin YC, et al. Does coffee drinking have beneficial effects on bone health of Taiwanese adults? A longitudinal study. BMC Public Health. 2018;18:1273. doi: 10.1186/ s12889-018-6168-0

15. Heckman MA, Weil J, de Mejia EG. Caffein (1,3,7-trimethylxanthine) in foods: A comprehensive review on consumption, functionality, safety, and regulatory matters. J Food Sci. 2010;75(3):R77-87. doi: 10.1111/j.17503841.2010.01561.x

16. Hallström H. Byberg L, Glynn A, et al. Longterm coffee consumption in relation to fracture risk and bone mineral density. Am J Epidemiol. 2013;178:898-909. doi: 10.1093/aje/kwt062

17. Choi EJ, Kim KH, Koh YJ, et al. Coffee consumption and bone mineral density in Korean premenopausal women. Korean J Fam Med. 2014;35:11-8. doi:10.4082/kjfm.2014.35.1.11

18. Hallström H, A. Wolk, A. Glynn, et al. Coffee, tea and caffeine consumption in relation to osteoporotic fracture risk in a cohort of Swedish women. Osteoporos Int. 2006;17:1055-64. doi: 10.1007/s00198-006-0109-y

19. Lacerda SA, Matuoka RI, Macedo RM. Bone quality associated with daily intake of coffee: A biochemical, radiographic and histometric study. Braz Dent J. 2010;21(3):199-204. doi: 10.1590/ s0103-64402010000300004

20. Geddes JAA, Inderjeet CA. Evidence for the treatment of osteoporosis with vitamin D in Residential care and in the community dwelling elderly. Bio Med Res Inter. 2013;2013:463589. doi: 10.1155/2013/463589

21. Kim MK, Chon SJ, Noe EB, et al. Assotiation of dietary calsium intake with metabolic syndrome and bone mineral density among the Korean population: KNHANES 2008-2011. Osteoporos Int. 2017;28:299-308. doi:10.1007/s00198-016$3717-1$

22. Hayati S, Herwana E. Peningkatan kalsium menghambat penurunan kepadatan tulang pada perempuan pascamenopause. J Biomedika Kesehat. 2018;1(2):145-51. doi: 10.18051/ JbiomedKes.2018.v1.145-151

23. Chiodini I, Bolland MJ. Calcium supplementation in osteoporosis: useful or harmful? Eur J Endocrinol. 2018;178:D13-25. doi: 10.1530/EJE18-011

24. Choi MK, Kim MH. The association between coffee consumption and bone status in young adult males according to calsium intake level. Clin Nutr Res. 2016;5(3):180-9. doi: 10.7762/ cnr.2016.5.3.180

25. Nahas E, Kawakami MS, Nahas-Neto J, et al. Assessment of risk factors for low bone mineral density in Brazilian postmenopausal women. Climacteric. 2011;14:220-7. doi: 10.3109/13697137.2010.490969

26. Boskey AL, Coleman R. Aging and bone. J Dent Res. 2010;89(12):1333-48. doi: $10.1177 / 0022034510377791$ 